\title{
MINIMUM WAGE POLICY: IS THERE ANY IMPACT ON LOW SKILLED WORKERS IN ELECTRICAL AND ELECTRONICS COMPANIES IN MALAYSIA?
}

\author{
Vally Senasi* \\ Universiti Utara Malaysia \\ Samihah Khalil @ Halim \\ Universiti Utara Malaysia \\ Balakrishnan Parasuraman \\ Universiti Malaysia Kelantan
}

\begin{abstract}
Wage are the greatest pushing factor for many workers to work and positively relates to employee life satisfaction. Meanwhile, fringe benefits improve the skills and knowledge of workers and enhance the organization's reputation. Minimum wage policies around the world uphold the principle to provide a basic living wage for their workers. Nevertheless, the impact of national minimum wage policy on Malaysian employees, in particular, was the least explored since enacted into law in 2012. This study examines the minimum- wage impact on low-level skilled workers in the electrical and electronics industry in Malaysia. Minimum wage can have an effect on labor productivity and fringe benefits, particularly training, allowances, and insurance, have become important research topics. As such, this research discusses the effect of minimum wages on labor productivity and fringe benefits of employees. A semi-structured survey questionnaire was distributed to 600 employees in electrical and electronics firms in Penang and Kulim Industrial Zones. Data from 432 questionnaires were quantitatively analyzed using Exploratory Data Analysis (EDA). The findings suggest that employers should make some adjustments in administering the wage scale due to the implementation of minimum wage national policy that has impacted firms' costs and incomes. The results also found that the minimum wage affects labor productivity and wage differences among workers. Meanwhile, the minimum wage does not adversely affect the adjustments to the fringe benefits, except for the provision of training. This study recommends more strategic plans and negotiations between stakeholders on wage and fringe benefits that would warrant continuous positive effects for both workers and employers.
\end{abstract}

Keywords: Minimum Wage, Low-level Skill, Labor Productivity, Fringe Benefits, Malaysia.

Received: 17 July 2019

Accepted: 30 December 2020

https://doi.org/10.33736/ijbs.3186.2021

\footnotetext{
- Corresponding author: Vally Senasi, School of Government (SOG), Universiti Utara Malaysia (UUM); Tel: (604) 928 7952; Email: vally@uum.edu.my; vallysenasi@gmail.com
} 


\section{INTRODUCTION}

Employee wages have a positive impact on their work satisfaction and are a key predictor of a company's reputation. To employees, wages are the main driving force for them to work aspiring for self-development, affiliation, and life achievement (Rachmawati, 2008; Senasi, Khalil \& Parasuraman 2018). Wage is considered to be a measure of one's performance and often is a main collective bargaining issue between the employer and employees. To date, collective bargaining rights have received considerable attention from every single employee through many government entities.

Fair and equitable wages would allow workers to lead a better life. A reasonable living wage is a remuneration needed for all workers to improve their quality of life. Therefore, minimum wage policy decisions around the world uphold the principle of providing their workers with a fair living wage. This wage policy will ensure that fair wages are paid to workers, thus reducing the exploitation of workers and alleviating poverty (Saari, Abdul Rahman \& Habibullah, 2016; International Labour Organization (ILO) (1992).

In Malaysia, the minimum wage issue has been debated for decades (Ramasamy, 1994). Despite the fact that the real labour productivity of Malaysia grew faster at 5.0 percent yearly over the decade compared to a mere 2.4 percent increase in average wages, many employers still object to its implementation. The first Minimum Wage Order was gazetted on 16 July 2012 and implemented on the 1st of January 2013 in Malaysia (Minimum Wage Order, 2013). The Minimum Wage Order requires employers with six employees and above to pay a monthly minimum wage of RM900 (USD 278) or MYR 4.33 (USD 1.34) per hour for workers in Peninsular Malaysia, or RM800 per month in Sabah, Sarawak, and Federal Territory of Labuan. Malaysia has adopted a minimum wage system since 2013, applying to all workers except domestic workers. There are two different rates; one for Peninsular Malaysia, and one for Sabah, Sarawak and Labuan Federal Territory. The Minimum Wage system continued to be applied with the latest Minimum Wage rate in 2018 standardized by the Pakatan Harapan (PH) government of RM 1,100 for all states in Malaysia. Subsequently, on $1^{\text {st }}$ February 2020, the Minimum Wage rate gazette anticipates increasing the Minimum Wage rate in cities and municipal areas for RM 1200. With the new Minimum Wage rate, the hourly rate stood at RM5.77 for cities and RM 5.29 for municipal. It also shows that Minimum wage rates in areas other than the City Council or Municipal Council area fixed at RM 1,100. Table 1 presents the Minimum Wage rates according to the number of working days in a week in Malaysia. 
Table 1: Latest Minimum Wage Rates in Malaysia

\begin{tabular}{|c|c|c|c|c|}
\hline \multirow[t]{4}{*}{ Monthly } & \multicolumn{3}{|c|}{ Minimum wages rates } & Hourly \\
\hline & \multicolumn{3}{|c|}{ Daily } & \\
\hline & \multicolumn{3}{|c|}{ Number of working days in a week } & \\
\hline & 6 & 5 & 4 & \\
\hline RM1,200.00 & RM46.15 & RM55.38 & RM69.23 & RM5.77 \\
\hline \multicolumn{5}{|l|}{ Chart 2} \\
\hline \multirow[t]{4}{*}{ Monthly } & \multicolumn{3}{|c|}{ Minimum wages rates } & Hourly \\
\hline & \multicolumn{3}{|c|}{ Daily } & \\
\hline & \multicolumn{3}{|c|}{ Number of working days in a week } & \\
\hline & 6 & 5 & 4 & \\
\hline RM1,100.00 & RM42.31 & RM50.77 & RM63.46 & RM5.29 \\
\hline
\end{tabular}

Source: Ministry of Human Resources, 10 January 2020.

From Table 1 above, Chart 2 shows that the hourly minimum wage rate is RM 5.29 to earn RM1,100 monthly. Although the daily minimum wage rates decrease as the number of working days increased, it is a clear picture for workers to work for longer hours per day to earn the sum of RM 1,100 per month. For example, a workers need to work 4 days for 12 hours to earn RM 63.48 daily minimum wage rates. It is a low wage for an increment in the statutory minimum wage rates in Malaysia of RM1,100 to RM1,200. Although the Malaysian Government has made its decision on the minimum wage policy following the recommendations of the National Wages Consultative Council and relevant stakeholders across the country, many parties have expressed mixed concerns about the implementation of the minimum wage policy. The Malaysian government is serious about its national wage policy implementation. However, more efforts are still needed by its entities to transform the nation into a high-income country by raising the employees' household incomes. (Gooch, 2012; Nurrachmi, Mad-Ahin, Waeowanjit, \& Naz Abdul, 2012). As for the employees, they have positive feelings towards the policy, but on the employers' side, the imposition of minimum wages would lead to increased labour costs, which would have adverse impacts on the profitability margin of the firm as well as the closure of their businesses in the long term. In the meantime, conventional economists have warned that minimum wage regulation can reduce the productivity of workers and restrict employment opportunities for workers (Peterson \& Stewart, 1969). However, Leu (2013) argues that the productivity of firms depends on the type of workers employed in a particular sector. For example, foreign workers are at the lowest productivity level compare with domestic workers.

In particular, the Electrical and Electronics $(\mathrm{E} \& \mathrm{E})$ industry often fuelled with low wages, overtime work, and the rejection of trade union rights (Sarah, Pathma, \& Monika, 2010). Electronics Industry Employees Union (EIEU) agrees that the major problems in this industry are oppressive trade unions and labour law in Malaysia. As a result, wage disparities and unequal wage among electrical and electronics employees are growing. Consequently, this work aims to investigate whether the introduction of a minimum wage has any impact on the $\mathrm{E} \& \mathrm{E}$ sector despite contributing millions of income to our country. Besides, the minimum wage rate that is revised at the national level every two years requires sectoral base data on the minimum wage. Therefore, this research expected to fill the gap of the sectoral (manufacturing) base data on minimum wage in Malaysia. 
Since the implementation of the minimum wage policy in Malaysia in 2013, only a few studies appear to link the effects of the minimum wage in Malaysia (see for examples: Teh, Sum \& Lee, 2015; Mohd Zaini, Sok-Ghee \& Sallahuddin, 2016; Ibrahim \& Said 2015; Parasuraman, Bidin \& Steven 2014; Leu, 2013; Zulkifli \& Mohd Azlan, 2002). Neither of these studies reflected on the impact of minimum wage on labour productivity and fringe benefits among low skill workers in Malaysia. So this study attempts to fill the gap. The objective of this study is to explore the effects of minimum wages on labour productivity (through efficiency and effectiveness of workers based on their attitude, knowledge, and work practices) and to examine the minimum wage effect on workers fringe benefits.

\section{LITERATURE REVIEW}

According to Cobb-Douglas (1928), the theory of production function emphasizes that capital and labor are the main input to the production output. Minimum wage plays an important role in safeguarding the interests of low skilled workers by supporting them. As posited by Freeman (1992) and Rutkowski (2003), minimum wages redistribute fair wage (earnings) to low paid workers and have the potential to reduce poverty, enhance productivity, and foster growth. Past studies have indicated that salaries are a key factor in encouraging workers to achieve higher productivity apart from the status and job satisfaction (Vough \& Asbell, 1979; Jenkins, Mitra, Gupta, \& Shaw, 1998). Wages are considered a source of pride, security, and satisfaction for employees. Labor wage standards, such as minimum wages, are expected to have an impact on efficiency and effectiveness in motivating and retaining the workforce (James, Mark, Paul, \& Monder, 2003). As such, cheap wages will create inefficient workers. Thus, paying workers more makes the employers valued, which leads to greater responsibilities in performing the job (Leonard, 2008).

Efficiency wages theory argues that the higher wage increase motivates the employees to increase their productivity (Akerlof, 1982; Akerlof \& Yellen, 1990). Efficiency wage theory attempts to explain how wages relate to output by reversing the traditional neoclassical order of determination from (marginal) output to wages. Efficiency wage theory claims that high wages would lead to involuntary unemployment, inducing workers to work harder to avoid being sacked (Bowles, 1985; Ho \& Yap, 2001; Yusof, 2008). Therefore, higher levels of work efforts increase workers' productivity rather than a reversal. Many studies positively support a close connection between the wages and productivity in the developed and developing economies (Forth, Mason, \& O'Mahony, 2002; Wakeford, 2004; Montuenga-Gómez, Fernández \& Romeu, 2007; Narayan \& Smyth, 2009). However, a study by Lee and Leu (2015) found that minimum wage does not have an impact on productivity for the capital-intensive industry. They argued that total production is based more on the demand and the full capacity of the machines.

Hashimoto (1981) argues that increased wages mandated by law (minimum wages) can cause employers to reduce various non-wage benefits for employees. Many other studies have also shown that the minimum wage has reduced employee fringe benefits. For instance, Hashimoto (1981) and Neumark and Wascher (2001) agreed that some employers are responding to increased wages by reducing training programmes designed to improve skills and knowledge of current jobs. Meanwhile, Mincer and Leighton (1980) argue minimum wage causes lost opportunities for training and careers. Reduction in the on-the-job training (OJT) is another effect of minimum wage on workers. 


\section{METHODOLOGY}

This quantitative study collected the data from non-managerial employees from industrial zones of Kulim and Bayan Lepas. The reason for choosing this type of survey is because it is an excellent method for measuring attitudes, opinions, beliefs, and orientations in a large population (Babbie, 2007; Hair, Celsi, Money, Samouel, \& Page, 2003). As this study involves low skill workers with lower educational backgrounds, they prefer to write or give short comments in the survey rather than answering long survey questionnaires. Therefore, close-ended questionnaires were used in this study by asking the agreement level of the minimum wage by productivity factors and changes in the motivation, effort, and commitment among the employees. Out of 600 questionnaires distributed, there are 432 returnable questionnaires, resulting in 72 percent of the response rate.

This study examines the minimum wage policy and its significant effects on the low skilled workers. The survey was selected to explain the attitude and opinions about the consequences of the minimum wage. The survey questionnaire is suitable for this study due to a large number of respondents involved in this research (Greene, 2007). Before distributing survey questions, a verification letter from the graduate school was sent to the employers to get their consent in meeting their employees. In some cases, the researcher had to use extended networks or entry points to distribute the questionnaires. Later, the collected data were analysed using an exploratory data analysis (EDA) to identify the relationship between minimum wage and labour productivity (Mahendran \& Turaj, 2012). EDA is able to discover patterns, differences and check assumptions using statistical and graphical representations (Tukey, 1977; Myatt, 2007).

\section{RESULTS AND DISCUSSION}

A total of 63.7 percent of the majority of low skill workers agrees that minimum wage does change their attitude (motivation, effort, and commitment), skill development, and work practices towards labour productivity. Figure 1 shows an agreement on minimum wage, which does affect labour productivity. Meanwhile, 31.3 percent have a neutral opinion on the minimum wage effect on labour productivity. Five percent of the workers disagree that minimum wage affects their productivity level. Overall, the majority of the workers agree that the minimum wage does make a difference in increasing labour productivity.

Figure 1: Minimum wage effects on labor productivity

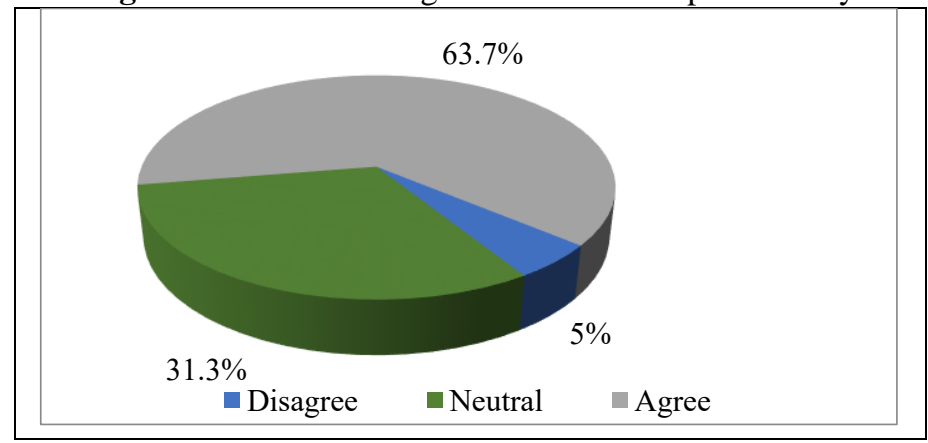


Parametric assumptions allow the samples to be drawn randomly from standard distributed populations and independent observations, consisting of an interval or ratio measurement scale that has equal variances in populations and resembles a normal distribution. If any sample breaks one of these rules, it means there is a violation of the assumption of the parametric test (Corder and Foreman, 2009). This study consists of nominal and ordinal data (categorical data), which violates the assumptions above, thus a nonparametric test is used for the purpose of data analysis (Kvam and Vidakovic, 2007). Therefore, these categorical data were analysed with chi-square and Spearman's rho correlation (Fink, 2006).

Table 2: Spearman Correlation Results for Minimum Wage Constructs According to Labor Productivity and Fringe Benefits

\begin{tabular}{ccccc}
\hline \hline \multicolumn{4}{c}{ Labor Productivity } & \multicolumn{3}{c}{ Fringe Benefits } \\
\hline $\mathrm{F}$ & $0.115^{*}$ & Insurance & Training & Allowances \\
$\mathrm{Sig}$ & 0.021 & -0.001 & -0.26 & -0.48 \\
\hline \hline
\end{tabular}

* Correlation is significant at the 0.05 level (2-tailed)

** Correlation is significant at the 0.01 level (2- tailed)

Table 2 above shows the Spearman's rho correlation test statistic $=.115$. The positive signs indicate a positive correlation. Moreover, the * illustrates that it is significant at the 0.05 level for a twotailed prediction. The actual $p$ value shows at 0.021 . By observing the Spearman correlation output matrix, it can be seen that the minimum wage (income level) is perfectly correlated with labour productivity. Hence, there was a Spearman's rho correlation coefficient of 1.000. Similarly, labour productivity is perfectly correlated with minimum wage, with a Spearman's rho correlation coefficient of 1.000 .

The test statistic value for Spearman correlation coefficient is .115 , and because the $\mathrm{p}$ value was smaller than 0.05 , it can be concluded that there is a significant difference between minimum wage (income level) and labour productivity $(\mathrm{p}<0.05)$. Alternatively stated, there is a positive relationship between minimum wage and labour productivity. The result is as follows:

$$
r S=.115, N=403, p<0.05
$$

The results show that there exists a significant correlation between minimum wage and labour productivity, as well as wage differences among the workers. This study found minimum wage increase motivation, commitment, and reduce the turnover rate among the employees. The results of this study correlate with the findings of (James et al., 2003; Blyton \& Jenkins, 2007; Narayan \& Smith, 2009; Zulkifly \& Mohd Azlan, 2002) who argued that minimum wages motivated the workers to increase effort and productivity. However, this study negatively correlates for constructs of fringe benefits, specifically training and allowances. This is due to training considered as a standard practice in which employers responsible to pay for the employees' training in the labour market (Becker, 1964; Acemoglu \& Pischke, 1998).

This study found that the minimum wage has a significant impact on labor productivity especially on non-managerial employees in the electrical and electronics (E\&E) sector. Thus, this is the high time for the government to focus on Productivity Linked Wage System (PLWS) to improve and to 
propel Malaysia into a high-income nation. The minimum wage was not well received by $1 / 3$ of the employers at the time of the study, but at the same time, the employer had invested in offering training to motivate employees. Government's enforcement on the compliance of minimum wage policy very much needed to ensure fair and equitable wages to all workers. Government could initiate incentives and tax relieves to those businesses implemented minimum wage policy as a source of encouragements. In addition, a shifting competitive advantage to the high paying labour market needs to have a minimum wage policy in practice. This policy will uplift the labour's income and help Malaysia to achieve the vision of becoming a high-income nation by the year 2020. Moreover, the minimum wage is the reward most low-skilled workers look forward to improving their standard of living.

\section{CONCLUSION}

In a nutshell, the new minimum wage rate is expected to increase a worker's financial capacity, impacting better standard of living. This study found minimum wage does increase the labor productivity in addition to fringe benefits such as training and allowances. Future studies on minimum wage should consider more sectors and areas impacted by the Minimum Wage Order (MWO). The practical usefulness and suggestions from this study hope to improve the working life and implementation of the minimum wage in Malaysia. Continuous research also needs to be conducted to fulfil the gap that has arisen from this research.

\section{REFERENCES}

Acemoglu, D., \& Pischke, J-S. (1998). Why do firms train? Theory and evidence. The Quarterly Journal of Economics, 113(1), 79-119. The MIT Press.

Akerlof, G. A. (1982). Labor Contracts as Partial Gift Exchange. The Quarterly Journal of Economics, 97(4), 543-569.

Akerlof, G. A., \& Yellen, J. L. (1990). The fair wage-effort hypothesis and unemployment. The Quarterly Journal of Economics, 105(2), 255.

Babbie, E. (2007). The practice of social research (11 th Ed.). Belmont: Thompson Wadsworth.

Becker, G. S. (1964). Human Capital: A Theoretical and Empirical Analysis, with Special Reference to Education. New York: National Bureau of Economic Research/Columbia University Press.

Blyton, P., \& Jenkins, J. (2007). Key concepts in work. Great Britain: Sage.

Bowles, S. (1985). The production process in a competitive Economy: Walrasian, Neo-Hobbesian and Marxian Models. The American Economic Review, 75, 16-36. American Economic Association.

Cobb, C., \& Douglas, P. (1928). A Theory of Production. The American Economic Review, 18(1), 139-165. Retrieved from http://www.jstor.org/stable/1811556.

Corder, G. W., \& Foreman, D. I. (2009). Nonparametric statistics for non-statisticians. A step-bystep approach. pp. 1-9. New Jersey, USA: John Wiley and Sons.

Fink, A. (2006). How to conduct surveys. A step-by-step guide (3rd ed.). USA: Sage Publications.

Forth, J., Mason, G., \& O’Mahony, M. (2002). Industrial performance, ICT investments and workforce skills: literature and statistical review. UK: National Institute of Economic and Social Research 
Freeman, R. B. (1992). Labor Market Institutions and Policies: Help or Hindrance to Economic Development? Washington. DC.

Teh, C. G., Sum, K. M., \& Lee, M. M. S. (2016). An initial review of the implementation of the Malaysian minimum wage order: A case for a win-win intention, implementation and enforcement. The Journal of Developing Areas, 49(4), 313-324.

Gooch, L. (2012). Malaysia enacts minimum wage. New York Times. Retrieved from http://www.nytimes.com/2012/05/02/business/global/malaysia-enacts-minimum wage. html?_r=0\&pagewanted=print on Wednesday September 26, 2012.

Greene, J. C. (2007). Mixed methods in social inquiry. USA: Jossey-Bass.

Hair, J. F., Celsi, M., Money, A. H., Samouel, P., \& Page, M. (2015). The essentials of business research methods ( $3^{\text {rd }}$ Ed.). New York: Routledge.

Hashimoto, M. (1981). Minimum wages and on-the-job training. The American Enterprise Institute for Public Policy Research. USA.

Ho, L. P., \& Yap, S. F. (2001). The link between wages and labour productivity: An analysis of the Malaysian manufacturing industry. Malaysian Journal of Economic Studies, 38(1-2), 51-57.

Ibrahim, N. A., \& Said, R. (2015). The implementation of the National Minimum Wages in Malaysia. Journal of Economics, Business and Management, 3(1), 125-130.

International Labor Organization (ILO) (1992). Minimum wages. Wage-fixing machinery, application and supervision. Geneva, Switzerland.

James, A., Mark, W. G., Paul, E., \& Monder, R. (2003). The impact of the National Minimum Wage in Small Firms. British Journal of Industrial Relations, 41(3), 435-456.

Jenkins, G. D., Jr., Mitra, A., Gupta, N., \& Shaw, J. D. (1998). Are financial incentives related to performance? A meta-analytic review of empirical research. Journal of Applied Psychology, 83(5), 777-787. doi: 10.1037/0021-9010.83.5.777

Kvam, P. H., \& Vidakovic, B. (2007). Nonparametric statistics with applications to science and engineering. New Jersey, USA: John Wiley \& Sons.

Lee, J. Y., \& Leu, J. F. Y. (2015). Will minimum wage translate into higher productivity? A case analysis of manufacturing firms in Malaysia. International Journal of Education and research, 3(4), 453-464.

Leonard, K. M. (2008). The minimum wage: Ethics and productivity. Journal of Collective Negotiations, 32(1), 77-87. US: Baywood Publishing Co.

Leu, J. F. Y. (2013). Minimum Wage Policy in Malaysia: Its Impact and the Readiness of Firms. World Applied Sciences Journal, 28, 19-26.

Mahendran, S., \& Turaj, V. (2012). Exploratory data analysis for almost anyone. Universiti Putra Malaysia Press. Serdang.

Mincer, J., \& Leighton, L. (1980). Effect of minimum wages on human capital formation. National Bureau of Economic Research, 441(6). Massachusetts. USA.

Minimum Wage Order 2013. (2013, May 28). Retrieved from http://minimumwages.mohr.gov.my/pdf/PGMPindaan2013.pdf

Minimum Wage Order 2020. (2020, January 10). Retrieved from http://minimumwages.mohr.gov.my/pdf/PerintahGajiMinimum2020.pdf

Mohd Zaini, A. K, Sok-Ghee, C, Sallahuddin, H. (2016). Minimum wage policy and country's technical efficiency. International Journal of Economics and Financial Issues, 6(4), 17291735.

Montuenga-Gómez, V., Fernández, M., \& Romeu, A. (2007). The link between wages and productivity in Spain. International Review of Applied Economics, 21(2), 247-272. 
Myatt, G. J. (2007). Making sense of data. A practical guide to exploratory data analysis and data mining. USA: John Wiley \& Sons.

Narayan, P., \& Smith, R. (2009). The effect of inflation and real wages on productivity. New evidence from a panel of G7 countries. Applied Economics, 41, 1285-1291.

Neumark, D., \& Wascher, W. (2001). Minimum wages and training revisited. Journal of Labor Economics, 19(3), 563-595.

Nurrachmi, R., Mad-Ahin, A., Waeowanjit, P., \& Naz Abdul, K. A. (2012). Optimal design for a minimum wage policy in Malaysia. MPRA Working Paper No. 44618.

Parasuraman, B., Bidin, C, K., Steven, C, A. (2014). The effects of minimum wage implementation: A literature analysis. Universiti Malaysia Kelantan (UMK). Retrieved from https:// www.academia.edu/10244313/2014_The_Effects_of_Minimum_Wage_Implementation_ A_Literature_Analysis_The_proceedings_of_the_International_Conference_on_Human_ Resource_Management_and_Organizational_Effectiveness_in_Asia_Pasific_Malaysia.

Peterson, J, M., \& Stewart, C. H. (1969). Employment effects of minimum wage rates. American Enterprise Institute for Public Policy Research. Washington, D. C.

Rachmawati, I. K. (2008). Manajemen sumber daya manusia. Penerbit Andi. Yokyakarta.

Ramasamy, P. (1994). Plantation labour, unions, capital, and the state in Peninsular Malaysia. New York: Oxford University Press.

Rutkowski, J. (2003). The minimum wage: Curse or cure? Human Development Economics Europe and Central Asia Region. Washington, D. C.: The World Bank.

Saari, M. Y., Abdul Rahman, A., Hassan, A., \& Habibullah, M. S. (2016). Estimating the impact of minimum wages on poverty across ethnic groups in Malaysia. Economic Modelling, 54, 490-502.

Sarah, B., Pathma, K., \& Monika, E. N. (2010). Migration in A Digital Age. Migrant Workers in The Malaysian Electronics Industry: Case Studies on Jabil Circuit and Flextronics. Berlin: WEED.

Senasi, V., Khalil, S., Parasuraman, B. (2018, July 24-27). The impact of minimum wage on low skill workers and management in selected Electrical and Electronics Companies in Malaysia. Paper presented at ILERA World Congress, South Korea. Retrieved from http://online.ilera2018.org/scientific_pdf_abs.html?ano=455.

Teh, C. G., Sum, K. M., \& Lee, M. M. S. (2015). An initial review of the implementation of the Malaysian minimum wage order: A case for a win-win intention, implementation and enforcement. The Journal of Developing Areas, 49(4), 313-324.

Tukey, J. W. (1977). Exploratory Data Analysis. Reading, PA: Addison-Wesley.

Vough, C. F., \& Asbell, B. (1979). Productivity, a practical program for improving efficiency. Amacom. New York. USA.

Wakeford, J. (2004). The productivity-wage relationship in South Africa: An empirical investigation. Development Southern Africa, 21(1), 109-132.

Yusof, S. A. (2008). The long-run and dynamic behaviors of wages, productivity and employment in Malaysia. Journal of Economic Studies, 35(3), 249-262.

Zulkifly, O., Mohd Azlan, S. Z. (2002). Cabaran globalisasi: Strategi ekonomi upah tinggi. Journal Ekonomi Malaysia, 36, 3-17. 